\title{
Traduzindo literatura latino-americana no Brasil contemporâneo, com Maria Paula Gurgel Ribeiro
}

Barbara Zocal Da Silva (FFLCH-USP)

Wilson Alves Bezerra (UFSCar)

Maria Paula Gurgel Ribeiro nasceu em São Paulo, Brasil, em 05 de março de 1962. Formou-se como Bacharel em Direito, pela Universidade de São Paulo (1986). Obteve o título de Mestra em Língua Espanhola e Literaturas Espanhola e Hispano-Americana, pela Faculdade de Filosofia, Letras e Ciências Humanas da Universidade de São Paulo (2001), com a dissertação Tradução de Águas-fortes portenhas, de Roberto Arlt; $e$ o de Doutora em Língua Espanhola e Literaturas Espanhola e Hispano-americana pela mesma faculdade, em 2008, com a tese Monteiro Lobato e a Argentina: mediações culturais.

Atua principalmente como tradutora literária, do espanhol para o português, e sua primeira tradução foi publicada em 1996. Aprendeu a língua por si só, é autodidata, mas foi se especializando e aprimorando seus conhecimentos com os anos. Maria Paula Gurgel Ribeiro traduz principalmente contos e romances, mas também já traduziu vários ensaios, algumas peças e documentários.

Editores (doravante E): Conte-nos quando e como você começou sua carreira na tradução literária. Como eram o mercado e a demanda por traduções naquele momento?

Maria Paula Gurgel Ribeiro (doravante MP): Comecei fazendo um teste na editora Iluminuras, em 1996. Pouco depois, o editor Samuel Leon me convidou para a minha primeira tradução: Wasabi, do argentino Alan Pauls. Desde então, venho exercendo o ofício. 
E: Quem são (ou quais foram) seus principais contratantes?

MP: Meus contratantes são tanto editoras nacionais como Iluminuras, Globo, Edusp, N-1 Edições quanto internacionais, como a Alfaguara, entre outras.

E: Você estabelece um contrato formal com seu contratante? Há uma cláusula destinada aos direitos autorais?

MP: O contrato é elaborado pelas editoras. Trata-se de uma cessão dos direitos autorais da tradução.

E: Você escolhe as obras que traduz? De que liberdade você dispõe na hora de traduzir?

MP: Em geral são as editoras que fazem o convite para traduzir determinada obra, mas também já tive a oportunidade de propor a tradução de alguns textos. Sempre tive liberdade total na hora de traduzir.

E: Com qual frequência você recebe trabalhos de tradução?

MP: A cada cinco ou seis meses, mais ou menos.

E: Conte-nos um pouco sobre sua rotina de trabalho como tradutora: fale-nos sobre suas ferramentas (dicionários impressos, on-line, softwares de tradução etc.), as traduçoes chegam até você em papel ou formato digital, você usa computador ou máquina de escrever etc.?

MP: Uso principalmente dicionários impressos, seja para a língua espanhola seja para aqueles mais especializados, como dicionário de gíria, de moda, arquitetura etc. Como dicionário de português uso o Houaiss na versão digital e não uso softwares de tradução. Quando comecei a traduzir, em 1996, os originais chegavam até mim em papel. De alguns anos para cá têm chegado no formato digital. Sempre usei o computador para traduzir, mas na hora de ler a última versão do trabalho prefiro imprimi-lo, para facilitar o cotejo final. 
E: Quais objetivos orientam sua tradução (público alvo, instruções de editoras, tempo, preocupação com a relação forma, métricas, ritmo etc.)?

MP: Minha preocupação é sempre procurar manter o tom do texto original, o ritmo do texto bem como o estilo do autor. $\mathrm{O}$ tradutor deve utilizar os recursos da língua de chegada para criar o mesmo efeito do original, sempre levando em conta a cultura das duas línguas: a de partida e a de chegada.

E: Dentre as traducões que você realizou, qual você considera como a preferida ou a melhor experiência? Conte-nos algum caso singular de uma tradução sua (qual era o titulo da obra, quais foram os maiores desafios ou problemas enfrentados por você nesse trabalho, quais estratégias você utilizou para driblá-los? Comente-os.

MP: Minha tradução preferida é a de Os sete loucos \& Os lança-chamas (Iluminuras, 2000), do argentino Roberto Arlt, de quem venho traduzindo toda a obra. Em primeiro lugar, porque é um grande romance, de um autor que me arrebatou logo de cara. A tal ponto que decidi fazer no mestrado (na FFLCH-USP) a tradução das suas crônicas jornalísticas, as Águas-fortes portenhas, para estudá-lo com mais profundidade. Os desafios ao traduzir Os sete loucos \& Os lança-chamas foram enormes, porque o estilo de Roberto Arlt é uma mistura da linguagem coloquial dos subúrbios e as gírias, com a das suas leituras de folhetins, traduções e de palavras estrangeiras introduzidas na fala portenha através da imigração, sem contar com alguns neologismos e arcaísmos. Nesse sentido, o principal problema enfrentado foi em relação às gírias: encontrar uma boa solução para o lunfardo, a gíria rio-platense, e o vesre. No caso do lunfardo, procurei equivalentes tanto na gíria como na linguagem coloquial paulistana, devido à mesma imigração italiana. Por serem textos escritos nos anos de 1929 e 1931, respectivamente, procurei utilizar termos não muito atuais, na tentativa de criar ecos de uma linguagem não contemporânea. Já no caso do vesre, que é uma modalidade do lunfardo que consiste em inverter uma ou mais sílabas das palavras, depois de inúmeras tentativas desastrosas como adotar a língua do "p" e até mesmo a inversão das letras, optei por traduzir os termos. Uma curiosidade sobre este trabalho é que somente ao iniciar a tradução é que descobri que o início de Os lança-chamas era aquele teste que eu havia feito lá atrás, em 1996. Mais recentemente tive o privilégio de poder refazer a tradução, tantos anos depois, para uma nova edição (no prelo), da mesma Iluminuras. Foi uma experiência incrível essa de poder rever um trabalho e aparar as arestas da tradução, contando já com vários anos de experiência. 
E: Quem é referência para você no universo da tradução literária?

MP: Admiro vários tradutores, difícil me ater a um único: Modesto Carone, Boris Schnaiderman, Paulo Henriques Britto, Rosa Freire D’Aguiar, Paulo Schiller, entre muitos outros. Mas para ficar na minha área, o espanhol, cito a Josely Vianna Baptista.

E: Você, ao longo de sua carreira, tradų̊iu mais escritores ou escritoras? Quais você destacaria?

MP: Traduzi mais escritores, dentre os quais destaco: Roberto Arlt, Antonio Di Benedetto, Jorge Luis Borges e Bioy Casares. Dentre as escritoras, a argentina Alejandra Pizarnik (A condessa sangrenta, Tordesilhas, 2011) e o filósofo espanhol Beatriz Preciado (Manifesto contrassexual. Práticas subversivas de identidade sexual, N-1 Edições, 2014), que hoje em dia assina Paul Preciado.

E: Como tradutora, você acredita que há alguma particularidade na literatura escrita por mulheres, seja quanto à forma ou quanto à escolba dos temas? Há algum gênero literário ou país predominante? Isso mudou ao longo de sua carreira?

MP: Não acho que haja uma especificidade. Acredito que isso dependa mais do estilo de cada escritora.

E: As diferenças apontadas na questão anterior têm a ver com a forma de escrita ou com a demanda do mercado editorial nacional?

MP: Não saberia dizer.

E: Você acredita que há alguma particularidade para traduzir literatura escrita por mulheres?

MP: Acredito que não. O importante, em qualquer tipo de tradução, é manter o tom do original e o estilo do autor.

E: Você considera que em algum momento de sua carreira como tradutora sofreu algum tipo de restrição, preconceito ou ingerência sobre seu trabalho pelo fato de ser mulher?

MP: Nunca. 
E: Que desafios enfrenta quem se dedica à tradução literária no Brasil atualmente?

MP: Além dos mesmos desafios que todos os que atuam na área cultural enfrentam, acredito que ainda falta um reconhecimento maior ao trabalho dos tradutores - literários ou não - tanto nas resenhas jornalísticas quanto nas capas dos livros. Felizmente isso vem mudando desde que eu comecei a traduzir, mas às vezes ainda encontramos resenhas que não mencionam o tradutor.

E: Você costuma trabalhar em casa ou se dirige a outro espaço? Qual é a relevância do espaço na sua rotina de trabalho?

MP: Trabalho sempre em casa. É onde estão todos os meus dicionários, bem à mão, e onde me concentro melhor.

E: Vocêpoderia nos confidenciar alguma mania sua? Para onde seus olhos fogem quando querem descansar da tela do computador ou enquanto você pensa numa solução tradutória mirabolante? O que há na sua mesa durante o trabalho de tradução?

MP: A minha válvula de escape é a música, que sempre me ajuda a relaxar. E também já me ocorreu inúmeras vezes de, numa caminhada no parque, encontrar a solução para uma questão tradutória complicada. Durante o trabalho a minha mesa sempre tem dicionários, lapiseira e borracha (para fazer anotações na versão impressa da tradução).

E: Quais motivações inspiram você a seguir nessa profissão?

MP: É sempre muito bom poder apresentar novos autores ou novas obras de autores já conhecidos para os leitores.

Recebido em: 11/12/2017. 